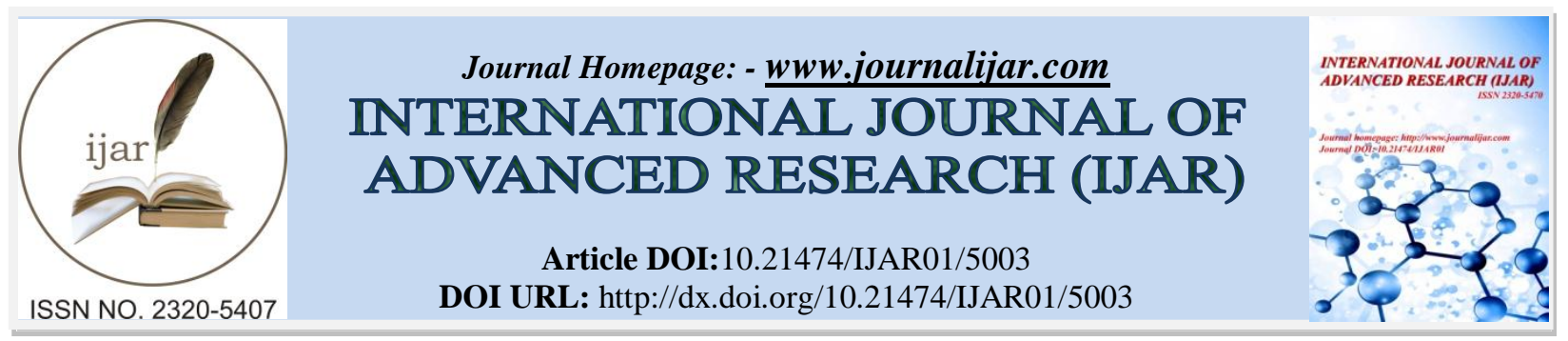

RESEARCH ARTICLE

\title{
IS LEADERSHIP IS A REACTIVE OR PROACTIVE THAT IS MOST ESSENTIAL FOR SUCCESSFULLY MANAGING PROJECTS?
}

\author{
Panyam Babu Veera Prasad ${ }^{1}$ and Dr. Kiran Kumar Reddi ${ }^{2}$. \\ 1. ResearchScholar, Rayalaseemauniversity, Kurnool,A.P,India . \\ 2. Department of Computer Science, Krishna University, Machilipatnam,A.P, India.
}

\section{Manuscript Info}

.......................

Manuscript History

Received: 29 May 2017

Final Accepted: 31 June 2017

Published: July 2017

Key words:-

Proactive Leadership, Project

Management, Successful Projects.

\section{Abstract}

With the highly competitive, challenging and cutting edge global business environment successfully managing projects is a real challenge. Proactive Leadership is emerged as champion in successfully managing projects in $21^{\text {st }}$ century. Through the advancement of latest technologies, rapid improvement in communications, and information technology changed the living style,standards, and rapidly changing cultures day by day. The day's are gone for the earlier type of Leadershippractices where success was achieved with traditional traits of leadership. Especially managing millennialis the need of the hour.Though success is a relative term, proactive Leadership has every edge on all, in increasing probability of success of projects.Myth was, leaders were born which was proved to be modified, as leader's are not only born and but also can be cultured and nurtured to suit the present requirement and also for future. The keywords for leadership failure are Arrogance, Autocratic and egoistic approach. Teams of self-motivated leaders are essential for driving and guiding successful projects. Leadership requires technical and non-technical skills in different proportions depending on the projects. There is every need for training, upgrading project managers as successful project Leaders which will reduces project time and cost and there by improves quality and satisfaction to the end users, so that the fruits of successful project management will lead to improve the standard of living. ofglobal society.

Copy Right, IJAR, 2017,. All rights reserved.

\section{Introduction:-}

Visionary leadership leverages the big picture perspective, and original ideas to envision business solutions that make waves in the marketplace, for a sustained period of time. Outstanding leadership has the capacity to achieve organizational success in spite of poor plans and/or poor organizations. On the contrary, the best of plans and/or organizations will fail under poor leadership. Successful leaders are those who implement the latest techniques in understanding the surroundings including the highly resourceful human beings. The whole world history reveals, success cannot be separated from the efforts of human resource and project management is not an exception to this. Today's majority of the software projects fail mainly because of insufficient importance of human resource. Leadership is mainly influencing character on which successful leaders emerge. Leaders are not only born rather 
leaders are created \& emerges from naturally best among the available lot. The essence of leadership is based on humanitarian approach towards colleagues, peers, superiors, and sub-ordinates with 360 degrees co-operation for mutual benefit. In Indian software industry really successful projects are very few due to Budget,Quality and Schedule blowouts.

The most important aspect of the research is discovering why projects fail, so that proper prevention and care can be taken in advance for successfully managing the projects. The main reason for failure is mismanagement. Estimate and control risk factors with highly skilled and experienced Project Leaders. Excellent Project Managers must possess down to earth, role model and Proacive Leadership qualities. Every Leader must believe \& realize that they must be cultured to manage allactivities, at all times, performing good for all i.e. for organization, tothe team members and also to the society at large in "humanitarian approach". We can't despair of humanity, since we ourselves are human beings as quoted by "Albert Einstein". Without the essence of the above "all Projects are bound to fail".

What are the reasons for projects Success or failure. Based on the Standish report 2016, 71\% of software projects are either challenged or ended in failure and only $29 \%$ projects are successful as shown in the chart 1.From 1994 to 2015 (14 years) it is reported that the average successful projects are $29 \%$, challenged $42 \%$ and failure $22 \%$ as per data analysed in table 1 .

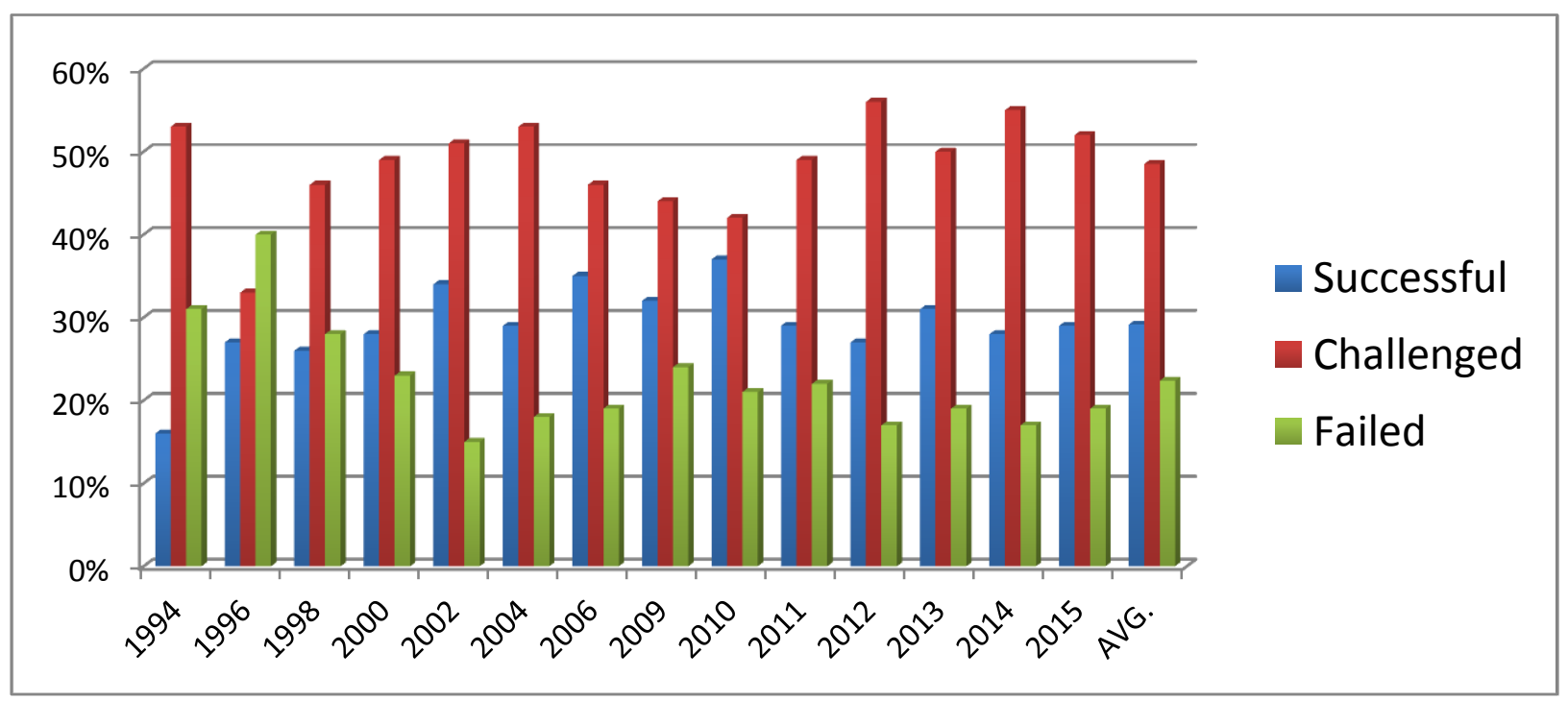

Chart 1 :- Standish reports \% of Success, Challenged and Failure from 1994 to 2015 (14 years).

Table 1:- Chaos resolution by Project Size (2011-15)

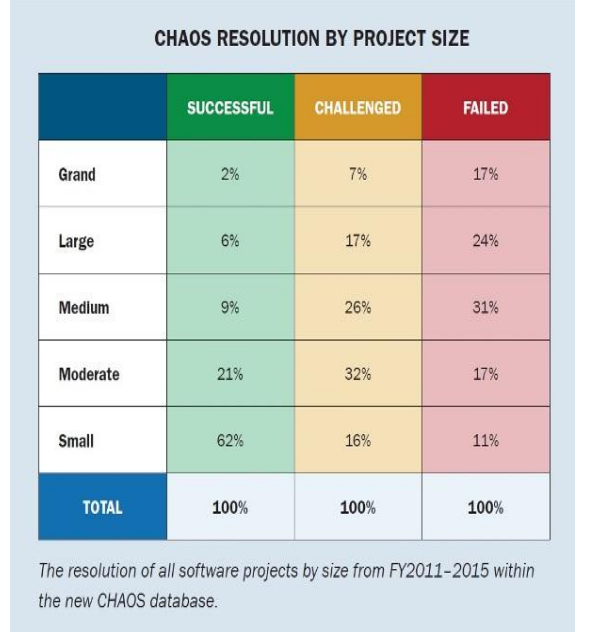

Table 2:- Chaos resolution by Agile Vs Waterfall model(2011-15). 


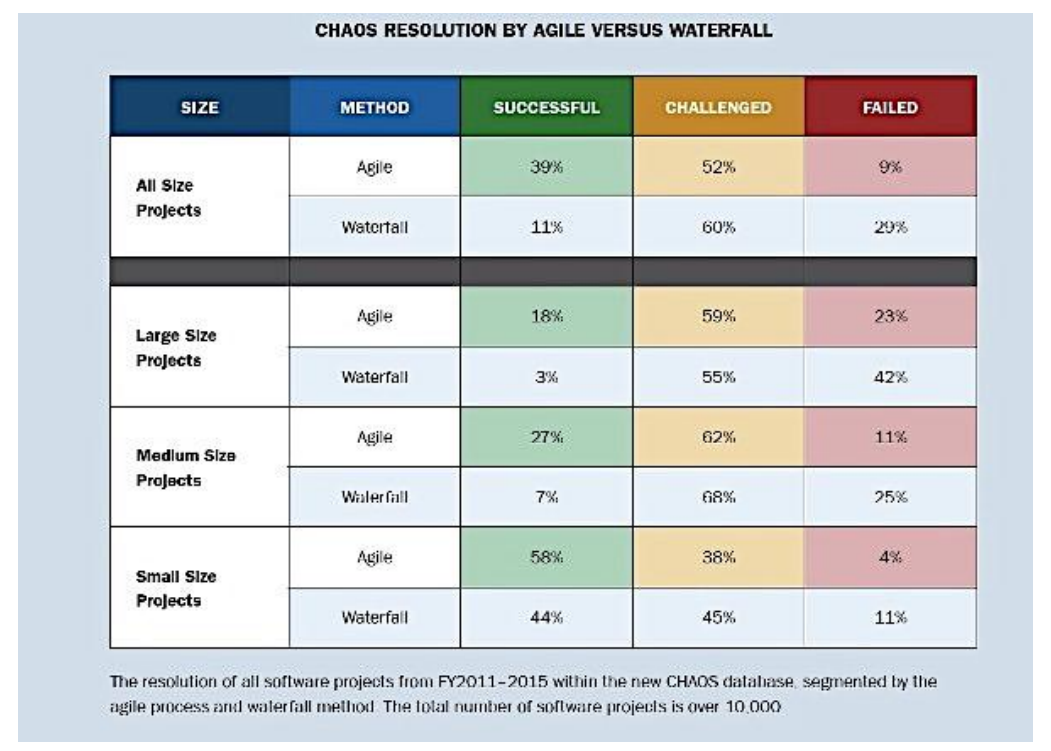

Chaos resolution by project size from 2011- 2015 as shown in Table 1, reveals that software projects outcome is based on the size of the project like Grand,Large,Medium,Moderate and small. Success rate is very high(62\%) in small size projects and only $2 \%$ in grand size projects which shows that success rate is inversely proportional to the size of the project. In the case of challenged projects, inversely proportional inference can be drawn except small size projects and also it looks like challenged projets are more or less normally distributed. Similarly failure projects are inversely proportional except for small and moderate size projects and also it looks like failure projets are more or less normally distributed with different degree of skewness.

Furthur analysis of data as shown in Table 2, based on the method adopted in software projects like traditional waterfall and latest agile and the size of the projects like small, medium and large, agile method is highly successful comparing with waterfall model.For small size projects Agile success rate is $58 \%$ and for large scale it is $18 \%$. This is clear from the data that managing or leading the large size projects successfully is becoming difficult for the present management as it is becoming complex. The gap is to be filled with the innovation, which is the present day's challenge for all proeject management related persons.

As per Standish CHAOS report the key factors for successful, Challenged and failure which contributes in improving probability of success are,

\section{Successful Projects:-}

1. User involvement

2. Executive management support

3. Clear statement of requirements

4. Proper planning

5. Realistic expectations

\section{Challenged projects:-}

1. Lack of user involvement

2. Incomplete requirements

3. Changing requirements and specifications

4. Lack of executive support

5. Technical incompetence

\section{Failure projects:-}

1. Incomplete requirements

2. Lack of user involvement

3. Lack of resources

4. Unrealistic expectations 
5. Lack of executive support

6. Changing requirements

7. Lack of planning

8. Did not need it any longer

9. Lack of IT management

10. Technical illeteracy

From the above factors it is noticed that the "user involment" is listed in either at no. 1 or 2 in all. It means the user involvement is one of the most commonn factor for making the project success.

\section{Lessons learnt from CHAOS reports:-}

1. Cusomer satisfation is also to be considered for successful projects.

2. For increasing probability of success of projects

a. Small size projects are to be considered.

b. Agile projects shall be preferredand not waterfall model.

c. Training of agile teams.

\section{What is Success?}

As per Project Management Institute (PMI), Project success is measured by product and project quality, timelines, budget compliance and degree of customer satisfaction.

Merrium-Webster dictionary defines success as the fact of getting or achieving wealth: respect or frame:the correct or desired result of an attempt; some one or something that is successful; or a person or thing that succeeds.

Standish group latest report includes 6 factors for measure overall success and they are,

1. On time

2. On Budget

3. On Target

4. On Goal

5. Value

6. Satisfaction.

Everyone aims to become successful in professional, Business and personnel life. Success is always relative to the needs. Success to one may not mean to besuccess to other. When projects are executed as per plan then it is regarded as succes.Performance and success both are not same, for example, highly performing organisations are not successful and could not sustain for long, because of rapid technology changes and lack of visionary leadership. Hence one needs to be creative and change with time for sustaining success.

\section{Levels of Success:-}

As per Mr. Brendan Foley, in his book " 5 states of success" describes 5 levels of success as,

1. The state of INSIGHT: Creates CLARITY to allow logical and creative thinking to unite.

2. The state of CONNECTION: Creates EMPATHY to build relationships with others.

3. The state of CERTAINTY: Creates CONVITION to proceed based on intuitive wisdom.

4. The state of VITALITY: Creates ACTION to create real and meaningful success.

5. The state of SPIRIT: Creates PURPOSE that builds uniqueness and Leadership.

\section{Elements of success:-}

1. Time

2. Cost

3. Quality

4. Scope

5. Satisfaction

As per John C Maxwell as explained in the book “ Leadership 101"for real success one must master skills like

1. Relationship

2. Equipping

3. Attitude

4. Leadership 
Role of Leadership for successfully managing projects, Questions in the minds of people:-

What way Leadership is responsible for the Success or failure of the projects? Can we reduce or eliminate failures by Proactive Leadership? These are some of the million dollar questions in the mind of the project related persons throughout the globe. With the expertise in projets management why succefull projects percentage is not increasing for more than 2 decades? How much of resources like effors, time and money was wasted? It is for the experts to analyse and plug the gap. Is it the fact theat projects related leadership is still following the grand old and outdated reactive leadership style of management? Have they started employing latest proactive leadership in Projects Management and what is the best mix of Proactive and reactive leadership. By answering such questions leads to successful project management.

\section{Project management nomenclature:-}

The Project Management Institute Body of Knowledge (PMBOK) is the preeminent global standard for project management.

\section{Budget:-}

Quantitative expression of a plan, from a financial aspect, that helps managers coordinate and implement the plan.

\section{Challenged Project:-}

A project that is late, over budget, and/or with less than the required features and functions.

\section{Competitive Advantage:-}

Defines an organization that sustains profits that exceed the average for its industry Cost Management: Includes processes involved in planning, estimation, budgeting, and controlling cost so that the project can be completed within the budget (monitor the cost constraint of the triple constraint issues)

\section{Deliverable:-}

Any unique and verifiable product, result, or capability to perform a service that must be produced to complete a process, phase, or project

\section{Earned Value Analysis (EVA):-}

An industry standard method of measuring a project's progress at any given point in time, forecasting its completion date, and final cost.

\section{Failed Project:-}

A failed project that is cancelled prior to completion or delivered and never used Organizational Culture: The organizational culture is a pattern of shared basic assumptions that was learned by a group as it solved its problems of external adaptation and internal integration that has worked well enough to be considered valid and, therefore, to be taught to new members as the correct way to perceive, think, and feel in relation to those problems.

\section{Project:-}

A project is as a temporary endeavor undertaken to create a unique product, service, or result Project Life Cycle: The phases that connect the beginning of a project to its commercial closure

\section{Project Management:-}

Project management is the application of knowledge, skills, tools, and techniques to project activities to meet project requirements

\section{Project Management Organization:-}

An organizational unit to centralize and coordinate the management of projects under its domain

\section{Project Manager:-}

A project manager is the person assigned by the performing organization to achieve the project objectives Project Performance: Project performance refers to the assessment of a project at its completion.

\section{Project Success:-}

Project success denotes projects delivered on time, within budget, and meeting quality requirements Project Team 
and also meeting the requirement of customer satisfation: A project team is all the project team members from various disciplines, the project manager, and for some projects, the project sponsor

\section{Project Team Member or Team Member:-}

The project team member or simply team member is the person who reports directly or indirectly to the project manager, and who is responsible for performing project work as a regular part of their assigned duties

\section{Risk Management:-}

Includes the processes concerned with conducting risk management planning, identification, analysis, responses, and monitoring and control on a project. These processes are updated throughout the project

\section{Scope Management:}

Includes the processes required to ensure that the project includes all the work required, and only the work required, to complete the project successfully Schedule: The planned dates for performing scheduled activities, and the planned dates for meeting scheduled milestones

\section{Triple Constraint:-}

A framework for evaluating competing demands. The triple constraints is often depicted as a triangle where one of the sides or one of the corners represents one of the parameters being managed by the project manager or project team. In project management, these parameters are time, scope (performance), and cost of Work Breakdown Structure (WBS): A deliverable-oriented hierarchical decomposition of the work to be executed by the project manager or project team to accomplish the project objectives and create the required deliverables as shown in Figure 1(a) and 1(b).

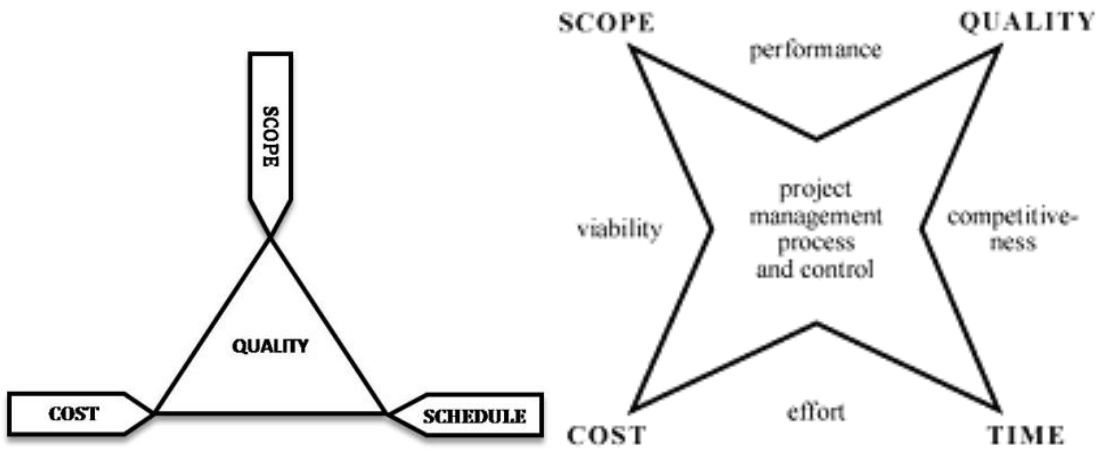

Figure 1(a):- Triple constraints $\quad$ Figure 1(b) :- Triple constraints detailed

\section{Leadership:-}

Undoubtedly, GOD ALMIGHTY is the ultimate Leader who created this universe. All religions and people over millions of years believe this fact. Defining leadership is highly challenging and dynamic task. At the time of writing this paper from only googlesearch engine "Difine Leadership" resulted about 24,90,00,000 hits and "Leadership" around 82,10,00,000 hits. Hence one's life is too short even to read about leadership completely.

Let's contribute the $24,90,00,001^{\text {st }}$ definition of leadership, we may enlarge the definition from Joseph C. Rost, leadership as follows: "Leadership is an influencing relationship among leaders and followers who intend change for mutual purpose". Here leaders and followers may interchange from situation to situation with time. It means leader in one situation may be the follower at different situation and vice versa. Here it is very important to note that, an individual possesses and exhibits many leadership qualities in life in many fields and situations with time.The Sine qua non of Change is Leadership.Leadership is influencing characteristic. Vision without action is fantasy; action without vision is random activity. The culture of team is a direct reflection of leadership. Primary job of leadership is to develop and cultivate team culture. Challenging status quo is leadership.

Some of theimportant and interesting leadership quotes are,

1. Leadership is capacity to translate vision in to reality - By Warren Bennis

2. Before you became a leader, success is all about growing you. When you become a leader, success is all about growing others - Jack Welch

3. Leadership is influence, nothing more, nothing less - John Maxwell 
4. Leadership is the art of getting someone to do something you want done because he wants to do it - Dwight D. Eisenhower

5. A drop of honey catches more flies than a gallon of gall - By Abraham Lincon

6. A Leader is dealer in hope - By Nepolian Bonaparte

7. A Leader is choice you make, not the position you sit on - By John Maxwell

8. A Leader is one who know's the way, goes the way and shows the way - By John Maxwell

9. A man can fail many times but he is not a failure until he gives up - By Anonymous

10. Leader's lights lives.

11. Proactive Leader ignites lives.

12. The challenge of Leadership is to be strong, but not rude, to be kind, but not weak, to be humble but not timid, to be proud, but not arrogant, to be respected, not feared -By Gus Lee

13. If you treat an individual as he is, he will remain as he is. But treat him as he could be, he will become as he would be - Goethe.

Leadership is about bringing people into the inner circle of a shared vision and keeping the group together. If a leader loses his or her followers in the process of achieving a goal, it has not been a success. The ability to combine strength of vision with building a cohesive team is what separates leaders. The best leaders get people to sacrifice and do what is best for the team and to enjoy it with out use of force and purely voluntarily.

\section{Levels of Leadership:-}

John C Maxwell in his book "5 levels of leadership" explains leadership levels in depth and excellently and those are,

1. Position: Rights: People follow because they have to

2. Permission: Relationships: People follow because they want to

3. Production: Results: People follow because what you have done for theorganisation

4. People Development: $\quad$ Reproduction: People follow because of what you have done for them

5. Pinnacle: Respect: People follow because of who you are and what you represent

The above levels of leadership explain about how leaders shall become successful and all fields in life and what people look for in successful leadership. Many projects are failing may be due to the fact that leaders may be operating at the level 1, merely sitting on the position and not moving to level's 2 to 5 . Many projects are challenged may be due to the fact that leaders may be operating at the level 1 and Level 2, merely sitting on the position and Permission not moving to level's 3 to 5. Similarly some projects are successful due to leaders are operating at the levels 3 and above.

\section{Styles of leadership:-}

Styles of Leadership Irrespective of the set of traits and skills acquired by leaders, theyperform their roles in a variety of styles. Their leadership behavior can be termed as autocratic, democratic or participative, and free-rein or hands off. Quite often, the leadership style depends on the situation, including where the organization is in its life cycle. The following leadership styles are very common.

\section{Autocratic:-}

The manager makes all the decisions and dominates team members. This approach generally results in passive resistance from team members and requires continual pressure and direction from the leader in order to get things done. Generally, this approach is not a good way to get the best performance from a team. However, this style may be appropriate when urgent action is necessary or when subordinates actually prefer this style. It is also very effective in an emergency or crisis situation.

\section{Democratic or Participative:-}

The manager involves the subordinates in decision making by consulting team members, while maintaining control. This style encourages employee ownership for the decisions. A good participative leader encourages participation and delegates wisely, but never loses sight of the fact that he bears the crucial responsibility of leadership. The leader values group discussions and input from team members and he maximizes he members' strong points in order to obtain the best performance from the entire team. The participative leader motivates team members by empowering them to direct themselves; he guides them with a loose rein. The downside to this style is that a participative leader may be seen as unsure, and team members may feel that everything is a matter for the group to 
discuss and decide.

Laissez-faire (also called free-rein):-

In this hands-off approach, the leader encourages team members to function independently and work out their problems by themselves, although he is available for advice and assistance. The leader usually has no control over team members, leaving them to sort out their roles and tackle their work assignments without personally participating in these processes. In general, this approach leaves the team floundering with little direction or motivation. Laissez-faire is usually appropriate highly motivated and skilled teams, and has a history of producing excellent work in an environment like the research and development. To gain popularity and self-gain, it is not uncommon that some manager resort to this style driving the project to perils.

In addition to the above, the following are other styles of leadership:

\section{Transactional:-}

This leadership style starts with the idea that team members agree to obey their leader when they accept a job. The 'transaction' usually involves the organization paying team members in return for their performance and compliance. The leader has a right to 'punish' a team member if his work is not up to the standard. Though this might sound controlling and paternalistic, transactional leadership offers a few benefits. This style of leadership clarifies everyone's roles and responsibilities. Since transactional leadership judges team members on performance, dynamic and ambitious team members are motivated with the extrinsic rewards associated. A downside to this leadership style isthat team members can do nothing to improve their job satisfaction. In such a situation, they can feel stifling and often leading to high staff turnover. In reality, transactional leadership is a type of management and not a leadership style, as the focus is on short-term tasks. This style offering myopic gains in other domains can have serious implications in creative work environment.

\section{Bureaucratic:-}

In this style, leaders work 'by the book.' They follow rules rigorously, and ensure that their people follow procedures precisely as well. This is an appropriate leadership style for work involving safety risks (such as working with machinery, with toxic substances, or at dangerous heights) or where large sums of money are involved. Bureaucratic leadership is also useful in organizations where employees do routine tasks (as in manufacturing). A downside to this style of leadership is that it is ineffective or counter-productive with teams and organizations that rely on flexibility, creativity, or innovation. Incidentally, bureaucratic leaders achieve their position because of their ability to conform to and uphold rules, not because of their qualifications or expertise. In such situations, ambitious and capable team member might resent or exit with frustration.

\section{Charismatic and/or Transformational Leadership:-}

This style can resemble transformational leadership because these leaders inspire enthusiasm in their teams and are energetic in motivating others to move forward. The excitement and commitment from the team yields enormous benefit. The difference between charismatic leaders and transformational leaders lies in their intention. Transformational leaders want to transform their teams and organizations. Charismatic leaders are often focused on themselves, and may not want to change anything. A downside to this kind of leadership is that the leader may believe more in himself than in his team. When this type of a leader leaves an organization, it can cause a great risk to the project or even the entire organization might collapse. A charismatic leader might be over confident that he can do no wrong, even when others are warning him about the path he is on. This feeling of invincibility can ruin sprit of the team or the entire organization. Quite often, a project manager with charismatic leadership for repeat success in projects is preferred by project sponsors and success is directly attributed to the charismatic leader. In view of this great responsibility, it needs a long-term commitment from such a leader.Leadership styles with associated behavior and it's advantages and disadvantages are listed in the table 3 .

\section{Who are Millennials?}

Millennials is the term applies to individuals who reached adulthood around the ruen of $21^{\text {st }}$ century. In the book of Generations, Neil Howe and William Strauss defined millennials as individuals born between 1982 and 2004. Millennials are also known as net generation or generation "Y" which follows generation "X". Their belief's and behavior's are different and more dreamy and more social. 


\section{Reactive and Proactive Leadership:-}

Leader's inherent ability to use reactive and proactive leadership qualities. For successfully managing projects what type of leadership is essential, like whether we require only proactive Leadership or only reactive leadership or both. In practical situations, we need to employ both the types of leadership but depening on business environment and situation. Some times proactive leadeship is counter productive. But majority of situations it is highly productive unlike reactive style. Hence proactive style is adopted for high yielding of success in project management. Here we take the help of Proactive type of Leadership.

Table 3:- Leadership styles, behavior and it's advantages and disadvantages.

\begin{tabular}{|c|c|c|c|c|c|}
\hline \multicolumn{5}{|c|}{ Leadership styles and it's advantages and disadvantages } & \multirow[b]{2}{*}{ Remarks } \\
\hline S.No & Style & Behaviour & Advantages & $\begin{array}{c}\text { Disadvanta } \\
\text { ges }\end{array}$ & \\
\hline 1 & Autocratic & $\begin{array}{l}\text { Taking decisions without consulting } \\
\text { team members even with useful } \\
\text { inputs }\end{array}$ & $\begin{array}{l}\text { Quick decisions } \\
\text { when there is no need } \\
\text { for team input }\end{array}$ & $\begin{array}{l}\text { Demoralisat } \\
\text { ion and staff } \\
\text { turnover }\end{array}$ & $\begin{array}{l}\text { Lewin's } \\
\text { Leadership } \\
\text { style(1930 } \\
\text { ) }\end{array}$ \\
\hline 2 & Democratic & $\begin{array}{l}\text { Takes team members input for } \\
\text { arriving at final decision }\end{array}$ & $\begin{array}{l}\text { Encourages } \\
\text { creativity, High job } \\
\text { satisfaction,productiv } \\
\text { ity and enaged in } \\
\text { decision making }\end{array}$ & $\begin{array}{l}\text { Not suitable } \\
\text { for quick } \\
\text { decion } \\
\text { making }\end{array}$ & $\begin{array}{l}\text { Lewin's } \\
\text { Leadership } \\
\text { style(1930 } \\
\text { ) }\end{array}$ \\
\hline 3 & Laissez-faire & $\begin{array}{l}\text { Autonomy, Advice and support to } \\
\text { team members. }\end{array}$ & $\begin{array}{l}\text { Self motivated, } \\
\text { knowledgebale and } \\
\text { skilled team members } \\
\text { Job satisfaction }\end{array}$ & $\begin{array}{l}\text { No Control } \\
\text { and not } \\
\text { suitable for } \\
\text { all types of } \\
\text { team } \\
\text { members }\end{array}$ & $\begin{array}{l}\text { Lewin's } \\
\text { Leadership } \\
\text { style(1930 } \\
\text { ) }\end{array}$ \\
\hline 4 & $\begin{array}{l}\text { Blake- } \\
\text { Mouton } \\
\text { Managerial } \\
\text { grid } \\
\end{array}$ & $\begin{array}{l}\text { Concerned for people and concern } \\
\text { for production/tasks. Define } \\
\text { work,roles ,structure. Plan, organise } \\
\text { and monitor }\end{array}$ & $\begin{array}{l}\text { Participatory, } \\
\text { encourages team } \\
\text { work and creativie } \\
\text { collaboration } \\
\end{array}$ & $\begin{array}{l}\text { No major } \\
\text { disadvantag } \\
\text { e }\end{array}$ & $\begin{array}{l}\text { Blake } \\
\text { mounton } \\
(1964)\end{array}$ \\
\hline 5 & $\begin{array}{l}\text { Path goal } \\
\text { theory }\end{array}$ & $\begin{array}{l}\text { Team members want and need and } \\
\text { environment they are working }\end{array}$ & $\begin{array}{l}\text { Different approach } \\
\text { for different people } \\
\text { line highly capable } \\
\text { with comple jobs and } \\
\text { low capable with } \\
\text { ambigious jobs }\end{array}$ & $\begin{array}{l}\text { No major } \\
\text { disadvantag } \\
\text { e }\end{array}$ & 1971 \\
\hline 6 & $\begin{array}{l}\text { Transformatio } \\
\text { nal }\end{array}$ & $\begin{array}{l}\text { Integrity and high emotional } \\
\text { intelligence. Motivate people with } \\
\text { shared } \\
\text { communication. }\end{array}$ & $\begin{array}{l}\text { High productivity } \\
\text { and engagement of } \\
\text { all tem members }\end{array}$ & $\begin{array}{l}\text { No major } \\
\text { disadvantag } \\
\text { e }\end{array}$ & $\begin{array}{l}1978 \& \& \\
\text { further } \\
\text { developed } \\
1985\end{array}$ \\
\hline 7 & Bureaucratic & $\begin{array}{l}\text { Follows rules rigorously and ensure } \\
\text { people follow procedures precisely }\end{array}$ & $\begin{array}{l}\text { Suitable for routine } \\
\text { tasks and serious } \\
\text { safety risk tasks }\end{array}$ & $\begin{array}{l}\text { No } \\
\text { flexibility } \\
\text { or } \\
\text { innovation } \\
\text { or creativity }\end{array}$ & \\
\hline 8 & Charismatic & $\begin{array}{l}\text { Inspire and motivate team members } \\
\text { like transformational but not for } \\
\text { organisation but focus on self } \\
\text { ambitions and may not want to } \\
\text { change. Believe that they canot go } \\
\text { wrong and don't care about other's } \\
\text { warnings }\end{array}$ & $\begin{array}{l}\text { People gets attracted } \\
\text { towards GOD gifted } \\
\text { charima }\end{array}$ & $\begin{array}{l}\text { feeling of } \\
\text { invincibility } \\
\text { can damge } \\
\text { team and } \\
\text { organisation }\end{array}$ & \\
\hline
\end{tabular}




\begin{tabular}{|c|c|c|c|c|c|}
\hline 9 & Servant & $\begin{array}{l}\text { Perosn with no formal recognistion } \\
\text { of a leader. Regardless of leader } \\
\text { meete the requirement of the team. } \\
\text { High integrity and lead with } \\
\text { generosity. Lead by example. } \\
\text { Achieves power with values, ideals } \\
\text { and ethics }\end{array}$ & $\begin{array}{ll}\text { Creates } & \text { positive } \\
\text { corporate } & \text { culture. } \\
\text { High moral among } \\
\text { team }\end{array}$ & $\begin{array}{l}\text { Leaders will } \\
\text { be left } \\
\text { behind in } \\
\text { competetive } \\
\text { environment } \\
\text {. Not suited } \\
\text { for quick } \\
\text { decisions } \\
\text { and to meet } \\
\text { tight } \\
\text { deadlines }\end{array}$ & $\begin{array}{l}\text { Mahatma } \\
\text { Gandhi } \\
\text { style of } \\
\text { Leadership }\end{array}$ \\
\hline 10 & Transactional & $\begin{array}{l}\text { Organisation pay's for the effort and } \\
\text { compliance of the short term job. } \\
\text { Team member must obey the Leader } \\
\text { and accept the job. Defines roles and } \\
\text { responsibilities.Judges team } \\
\text { members on performance.Right to } \\
\text { punish team members if work does } \\
\text { not meet required standard }\end{array}$ & $\begin{array}{l}\text { Business transactions } \\
\text { on short term }\end{array}$ & $\begin{array}{l}\text { Ambitious } \\
\text { and } \\
\text { motivated } \\
\text { for external } \\
\text { rewards. } \\
\text { High staff } \\
\text { turnover. } \\
\text { Noknowled } \\
\text { ge base and } \\
\text { creative } \\
\text { work. Less } \\
\text { job } \\
\text { satisfaction }\end{array}$ & \\
\hline 11 & $\begin{array}{l}\text { Contextual } \\
\text { based }\end{array}$ & $\begin{array}{l}\text { Oppourtunity emerges when } \\
\text { environmental factors and individual } \\
\text { action come together }\end{array}$ & $\begin{array}{l}\text { New enterprised, new } \\
\text { products and services }\end{array}$ & & \\
\hline
\end{tabular}

\section{Proactive Leadership:-}

We can't control every thing. Being proactive means, focus on things we can control over to make things better and better for increasing success rate. Never focus on the thing, which we can't control.

Proactive people, change things in the intended direction for betterment. They always try to challenge the status quo. They prefer to lead the change unlike others. For example two persons on the same job perform differently. One may like to change in the direction for betterment actively and the other may tries to maintain the status quo and becomes good custodian and tries to just flow with the current. Proactive persons create change and hence they take moderate risk. Proactiveness involves creating change, not merely anticipating it. It does not just involve the important attributes of flexibility and adaptability toward an uncertain future. Taking initiatives in improving business is proactiveness. Other behavior that is not proactive includes sitting back, letting others try to make things happen, and passively hoping that externally imposed change "works out okay." People engage in many actions that can bring about change. But not all of them are truly proactive. First, change can be evoked unintentionally, for a negative as well as a positive outcome. This is not proactive behavior. Second, people can engage in cognitive restructuring by psychologically reframing or reinterpreting situations. This can be useful and beneficial, as when a threat is reconstrued as an opportunity, or a situation of high stress is viewed as controllable. It can also be detrimental, as when managers deny the existence of real problems, or convince themselves of the viability of an untenable strategy. This, too, is not proactive behavior, because it changes perceptions without changing reality. 


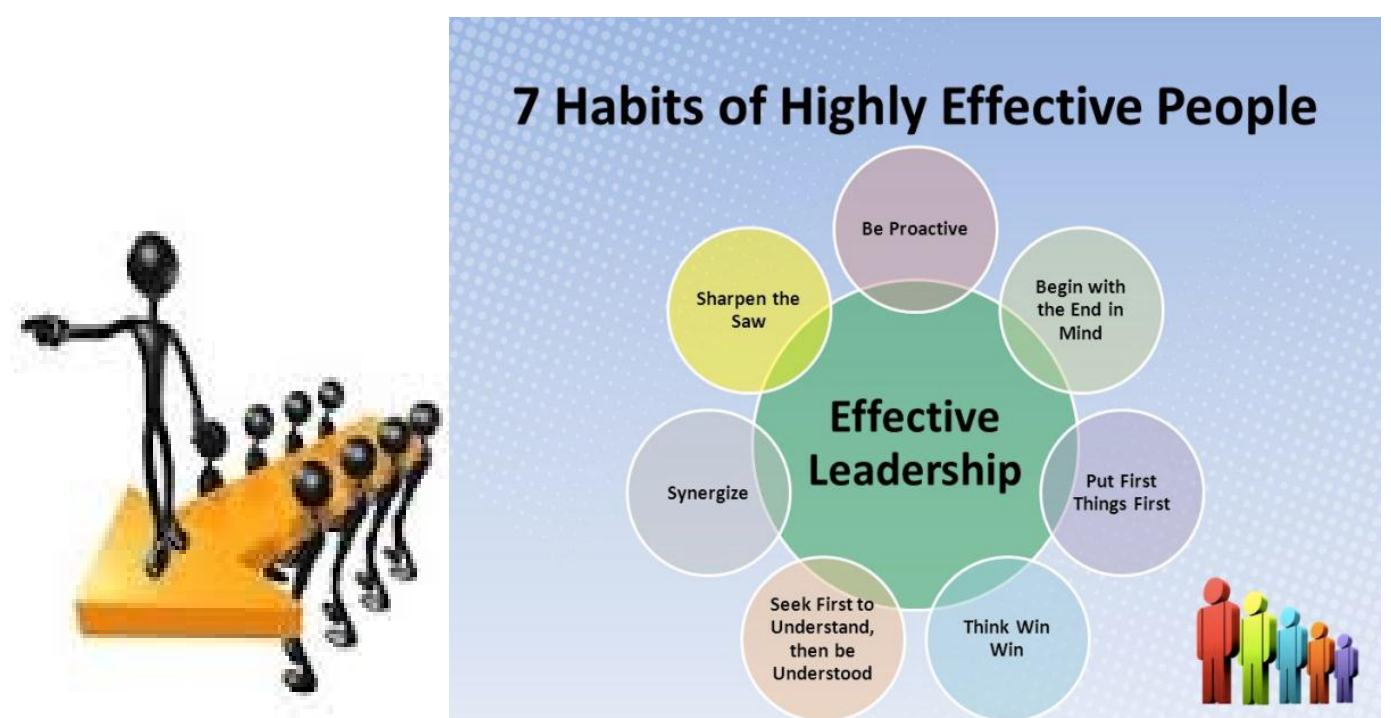

Figure 2:- Proactive Leader

Figure 3:- 7 Habbits of highly effective people by Stephen R. Covey

As shown in figure 2 above the Proactive leader leads team of followers by focussing converting vision in to reality.

Stephen R.Covey explained the 7 habbits of highly effective people, in which first habbit is be proactive. Recently $8^{\text {th }}$ habbit " from effectiveness to greatness" is added.

\section{Gifts of Nature:-}

1. Freedom to choose

2. Laws of nature

3. The 4 intelligences
a. Mental
b. Physical
c. Emotional
d. Spirutual

As per George Bernard Shaw, the world consists of 3 types of people

1. Those who make the things happen

2. Those who watch what happens

3. Those who wonder what happened

Strategy gurus Hamel and Prahlad also expressed similar opinion about the people saying on the road to future

1. There are drivers

2. There are passengers

3. There is road to kill

\section{What proactive people do?}

1. Doing the things differntly and definitely not the routine or tradictional way.

2. Set goals that involves change. For example empower clients for self sustainance

3. Prevents problems by anticipation

4. Searching for opportunities to growth and development.

5. First to do type like pioneering

6. Move forwared always and never step back and never settles for less.

7. Keep trying different way's.

8. Acievement oriented.

9. Inspires the follwers

10. Feed forward action 


\section{Charecteristics of a Proactive Leader:-}

1. A Sevant heart

2. Optimistic

3. Wise

4. Courage

5. Self controlled

6. Loving

7. Passionate

8. Encouraging

9. Honesty

10. Loyality

11. Perservance

12. Trustworthiness

13. Humility

14. Sensitivity

15. Teachability

16. Value driven

17. Even tempered

18. Gentle

19. Joyful

20. Consistent

21. Forgiving

22. Compassionate

23. Diserning

24. Fair

25. Patient

26. Kind

27. Merciful

28. Reliable

29. Empowerment

30. Faithful

31. Spiritual depth

Competencies of a Proactive Leader:-

1. Effective Communication

2. Vision- Identification, articulating, Casting

3. Motivating people

4. Challenge the status quo

5. Coaching and developing people

6. Synthesizing information

7. Persuading people

8. Iniating strategic action

9. Engaging in strategic thinking

10. Conflict resolution

11. Developing resources

12. Delegating authority and responsibility

13. Reinforcing commitment

14. Celebrating Success

15. Decision making

16. Team building 
17. Instigating evaluation

18. Creating a viable corporate culture

19. Maintaining focus and priorities

20. Upholding accountability

21. Identifying oppourtunities for influence

22. Relating everything to Gods plans and principles

23. Modeling the spiritual deciplines

24. Managing other Key Leader's

\section{Difference between Reactive and Proactive Leadership:-}

Normally effective leaders are proactive always' s. But in general in India context traditionally majority of leaders are reactive. Our experience in Indian industry for the last 3 decades, we have come across majority of them behaved predominantly reactive way. Definition of "proactive" in dictionary.com defines "serving to prepare for, intervene in, or control an unexpected occurrence or situation, esp. a negative or difficult one; anticipatory." On the other hand, when we refer to reactive leaders, we normally are referring to leaders who have their actionsdetermined by situations, therefore generally acting after the fact.

The reason why majority of leaders behave reactively may be due to

1. Fear factor

2. Ill prepared for leadership

3. Fear of making wrong decisions

Effective leaders get frustrated with the behavior of the reactive co-leaders.

Table 4:- The difference in mindset of Reactive and Proactive Leader's

\begin{tabular}{|c|c|c|c|}
\hline \multicolumn{4}{|c|}{ The Difference in Mindset } \\
\hline S.No & Description & Reactive Leader & Proactive Leader \\
\hline 1 & Type & Feedback & Feedforward \\
\hline 2 & Decisions on & Rules & principles \\
\hline 3 & For Changes & Reacts: Firefighting & Foresees and influences change. \\
\hline 4 & Solutions & $\begin{array}{l}\text { Needs to have and use own } \\
\text { answers }\end{array}$ & $\begin{array}{l}\text { Understands the power of and uses team in solving } \\
\text { problems }\end{array}$ \\
\hline 5 & Orientation & Tell & Coaching \\
\hline 6 & Decisions & Self & Requests that team members make decisions \\
\hline 7 & Efforts to get results & Pushes & $\begin{array}{l}\text { Shares a vision so compelling the team wants to } \\
\text { move towards it }\end{array}$ \\
\hline 8 & Direction & $\begin{array}{lll}\text { Teaches team to expect } \\
\text { direction }\end{array}$ & Teaches team to be self-reliant \\
\hline 9 & Concern & Self first & Models team work and concern for greater good \\
\hline 10 & Reports & Produces reports first & Creates and communicates values first \\
\hline 11 & Control & Aafraid of losing control & Knows giving up control yields the best outcomes \\
\hline 12 & Focuss & Finding and fixing problems & Focuses on achieving performance outcomes \\
\hline 13 & Mistakes \& errors & Quick to punish & Helps team to learn from errors \\
\hline
\end{tabular}

Visibility of Proactive Leader:-

Visibility of Proactive Leader is tabulated in the table 5, how the leader is visible to different team members.

Table 5:-Visibility of Proactive leader. $5 \mathrm{M}$ 's of Visibility

\begin{tabular}{|l|l|l|l|l|}
\hline & & I (Leader) & You (other) & Some more \\
\hline 1 & Model & Do it & & \\
\hline 2 & Mentor & Do it & Watch it & \\
\hline 3 & Monitor & Watch it & Do it & \\
\hline 4 & Motivate & & Do it & \\
\hline 5 & Multiply & & Do it & Train others \\
\hline
\end{tabular}




\section{Empowerment:-}

What does empowerment mean? Some people perceive that empowerment means they are free to do what they want to do or power to make decisions. Then this will lead to chaos like random movement of electrons and not aligned. Actually empowerment is meant for releasing power with in individuals in order to achieve the outstanding performance and the best results by creating culture.

Then how empowerment can be achieved? It is by tapping the every individual experience, knowledge,skills and motivating them. Every one must be made to enjoy achievement, ownership and growth. Hidden or un-tapped talent must be taken out of the individuals for delivering outstanding results.

Empowerment may be considered as capacity utilization factor of and individual. In general capacity utilization may be around 20- 25 percent and Project success depends on improving this factor to maximum extent possible.

Then the Leader's role is to maximize in capacity utilization to maximum extent say roughly about minimum 90 percent. In Indian context often middle management always complaints that there is less manpower with them so that are not able to deliver the goods. But compare with the global benchmark the manpower employed is higher. Then why less output. The reason is very simple that Indian managers are to occupy the thick like proactive Leaders role and capacity utilization of individuals must be increased on par with the global benchmarks. Always think for improvement and learn from other's how they are able to achieve the desired results. Rather try to match the better than the best.Release the power with in creating culture for every one benefit from win-win. Managers must become part of team members for facilitating the required outcomes.

\section{key's of empowerment:-}

1. Share information with every one

2. Create autonomy through boundaries

3. Teams become the hierachy

\section{Team member:-}

1. accountable for results

2. tangeble and intangeble benefits

3. Sense of ownership.

\section{How to increase the success rate of projects:-}

Success rate of software projects globally is only $29 \%$, which is very low. Even success rate of other projects are also more or less similar. To say it is not even the pass mark. It means $71 \%$ of the efforts; budget, and time is being not utilized properly due to many reasons. So we must analyze the reasons very minutely and economically solution are to be obtained. Let's assume if the successful projects are say above $60 \%$ then imagine the amount of saving or productivity we might of achieved by today. Software projects success rate multiplies the global Gross Domestic Product (GDP) as software is developed for creating or enhancing value in other sectors and we can name any sector for this purpose. We can contribute for the enhancing the standard of living of humans globally as people in many underdeveloped countries are starving for food. We can even see that in some places food grains are burnt due to lack of storage place and lack of preservation facilities and on the other hand acute shortage of food grains. This is only one example and similarly there are many examples to quote.

For detailed research study why the success rate is low and why failure rate and challenged projects rate is high we have studied the reasons as per the latest Standish report. Making use of Pareto analysis for this application we may broadly say that there are $20 \%$ of the reasons why $80 \%$ of the projects are not successful and also $80 \%$ of the reasons why remaining $20 \%$ of the projects are not successful.

Based on the Standish report the common important point for the successful, Challenged and failure is "User involvement". User involvement is related to proper utilization of human resources as per the requirement. Best utilization of the human resources is possible only if the best Leadership is in place in the organization. When we say the word Leadership people often thinks there is only one leader or few at the top. It is not the case. Leaders can be many and leadership evolves around the situations. Leader in one situation becomes the follower in another situation is the follower and vice versa. Depending on the situation most appropriate leadership styles as adopted by 
the leaders. Now as discussed above the Proactive leadership is having all the advantages for bridging the gap of user involvement.

Proactive leadership suits to the requirement by bridging the gap for making majority of the projects globally. Unlike reactive leadership, proactive leadership gives the necessary inputs before failure. Wise thing is adopting the proactive leadership at the earliest for increasing the success rate of projects. Mainly mindset has to change in the leadership and its all team members. Leader shall not isolate from the team members and shall act like one among them, so that the real problems the optimistic and best solutions can be provided in time. For example in the engineering related problems quality circles teams are formed for solving the small problems. We can't deny the fact that ocean is made of water drops. Similarly the big problems can be solved by the involvement of all the team members from the bottom of the heart. User involvement makes the projects successful. Actually changing the mindset of the people is most difficult task, but not impossible. The real leadership qualities are to be applied for changing the mindset of the people like influencing, making them understand the impact of failure and the subsequent consequences. Special trainings may be conducted to all the team members to contribute $100 \%$ of their capability.With the involvement of the experts in the related field we can reduce the impact if the could not be eliminated completely.

To make the head start we can say the point wise solutions may be like

1. Involve the projeect related pople for exact solutions like start forming quality circle for analyzing the real problems.

2. Start rating the leaders based on the secret factual feed back. Once this is done every member of the team becomes more sensitive and will have no option left other than changing the mind set. Actually people given optin they will not change unless there no option but to change.

3. Like standish reports country wise reporting shall start so the detialed analysis of failures can be documented and systemetised for better solutions.

4. Feedback system on performance of all the team members may be followed like matrix feed back in the way of marix management sytle.

5. Since the cost of the failure or challenged is going to be in order of few million dollars world wided we can say that the mindset changing cost may be near 2-3\% only. So we can gain a lot with small investment.

6. We have experienced that by implementation of 360 degree apprisal where in rating will depend on all superiors, peers, collegues and subordinates coverin $100 \%$ of the team members. Overlall complete rating will have best effect in improving the probability of success.

7. Pareto analysis for all the problems are to be implemented with detailed study.

8. Lessons learnt may be shared among all the industry leaders for esay improvements in that specific area.

9. Though competetion and business intelligence are the areas which organisations may not come up with the sharing of the solutions but at the longer run everyone is expected to loose.

10. Win-win approach will change the way how the people look for solutions.

11. Proactive leadership concept to be made to include in curriculam at all levels of primary education to Post graduation level by training. Since everyone shall be part of the development of the society at large.

12. Like golbal warming effors by all the nations there sahll be made global by conducting meetings by the Political and bureaucratic leaders to contribute their share in contributing for successfully managing projects.

13. Even at the level of the religious leaders proacive approah to be preached and encouraged so tha it becomes easy to adopt the change at the earleist and that too with little efforts as it is more effective.

14. Socalised leadership style of proactive leadership must implemeted at all levels in all organisations.

15. Most of the software persons are always's busy in doing the things with lot of hardwork but not really looking about the reasons of failures of the software projects.

16. Positive thinking and win-win approach will energise the people so that all the software projects can beome success.

17. Proactive leadreship shall be made as iterative model at all the phases of life cycle. So the the small small issues can be resolved at each and every stage and then so the project becomes successful. It shall be iterative model.

18. Proactive leadership must beocme an habbit like Behavioral Based Safety (BBS) which is implmented in the organisation world wide and found the increase in safety behaviour, so that it becomes Behavioural Based Success (BBS).

19. Proactive leadership shall be made as closed loop control system iteratively implemented at all levels and phases of the project. 
20. Proactive and ractive leaderships essential depending on the situatin, but majority say 90 percent of the time we may require Proactive approach and reamining $10 \%$ reactive depensidng on the situation.

\section{Findings:-}

There is possibility of making greater improvement in success rate of projects with little effort by employing proactive leadership in successfully managing projects by following the below mentioned methods.

A detailed questionnaire was presented to the Leaders and multiple teams, yielded positive responses supporting the consideration of the Proactive leadership for successfully managing projects.

1. Cusomer satisfation is also to be considered for successful projects.

2. For increasing probability of success of projects

a. Small size projects are to be considered.

b. Agile projects shall be preferred and not waterfall model.

c. Training of agile teams.

3. The main reasons for failure projects are mainly, no proper feed back system was in place as shown in figure 4 below.

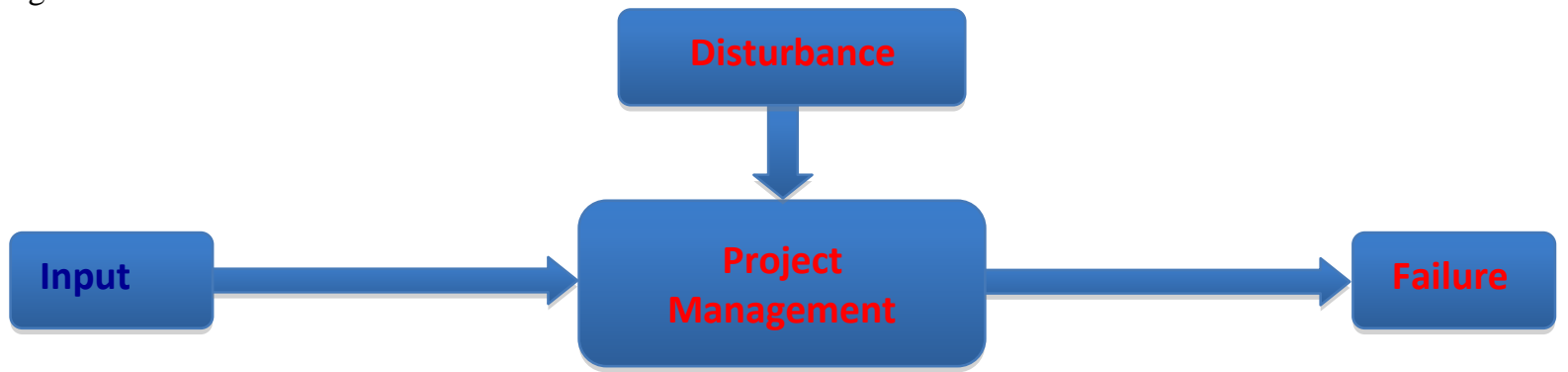

Figure 4:- Failure project

4. The main reasons for challenged projects are due to reactive type of leadership which was predoninant as shown in figure 5 below.

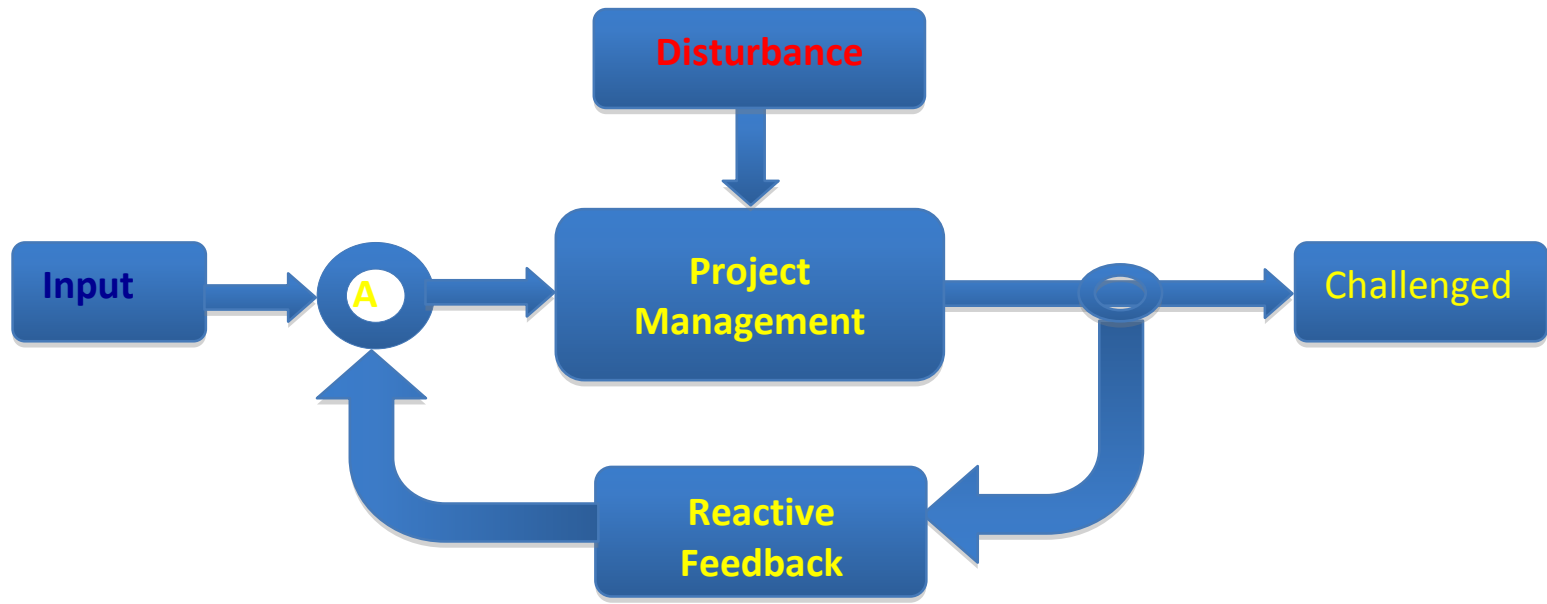

Figure 5:- Challenged project 
5. The main reasons for successful projects are proactive leadership and effective timely actions as shown in Figure 6 below.

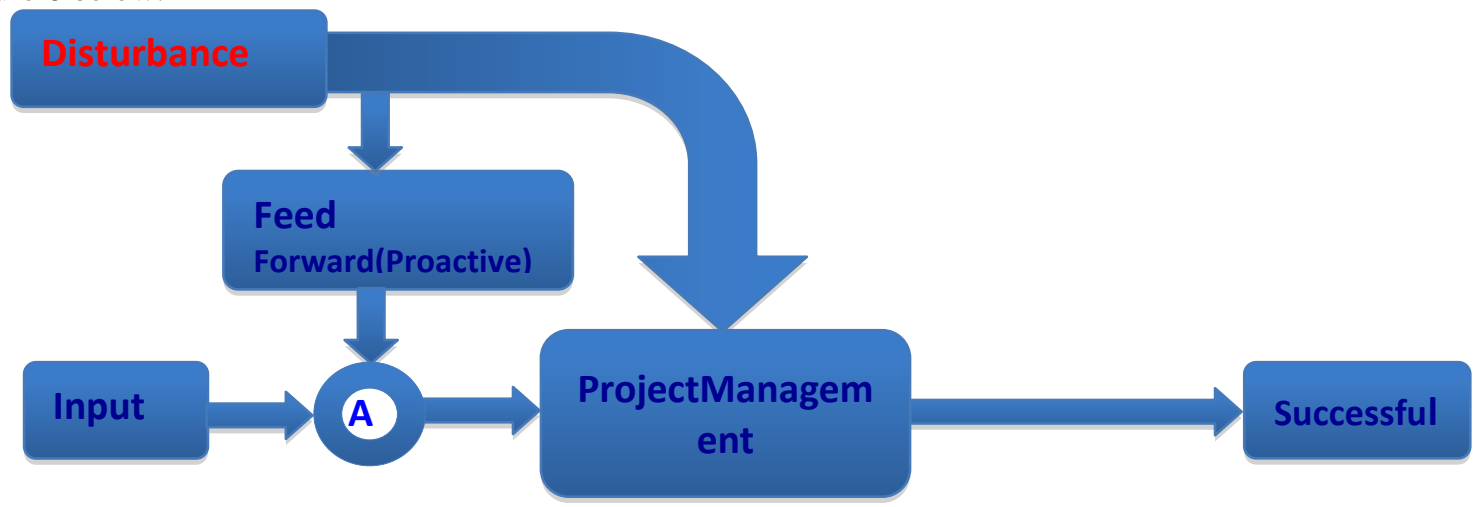

Figure 6:- Successful project

6. The main reasons for highly successful projects are proactive leadership and reactive leadership both were in place in different combinations as were required as shown in Figure 7 below.

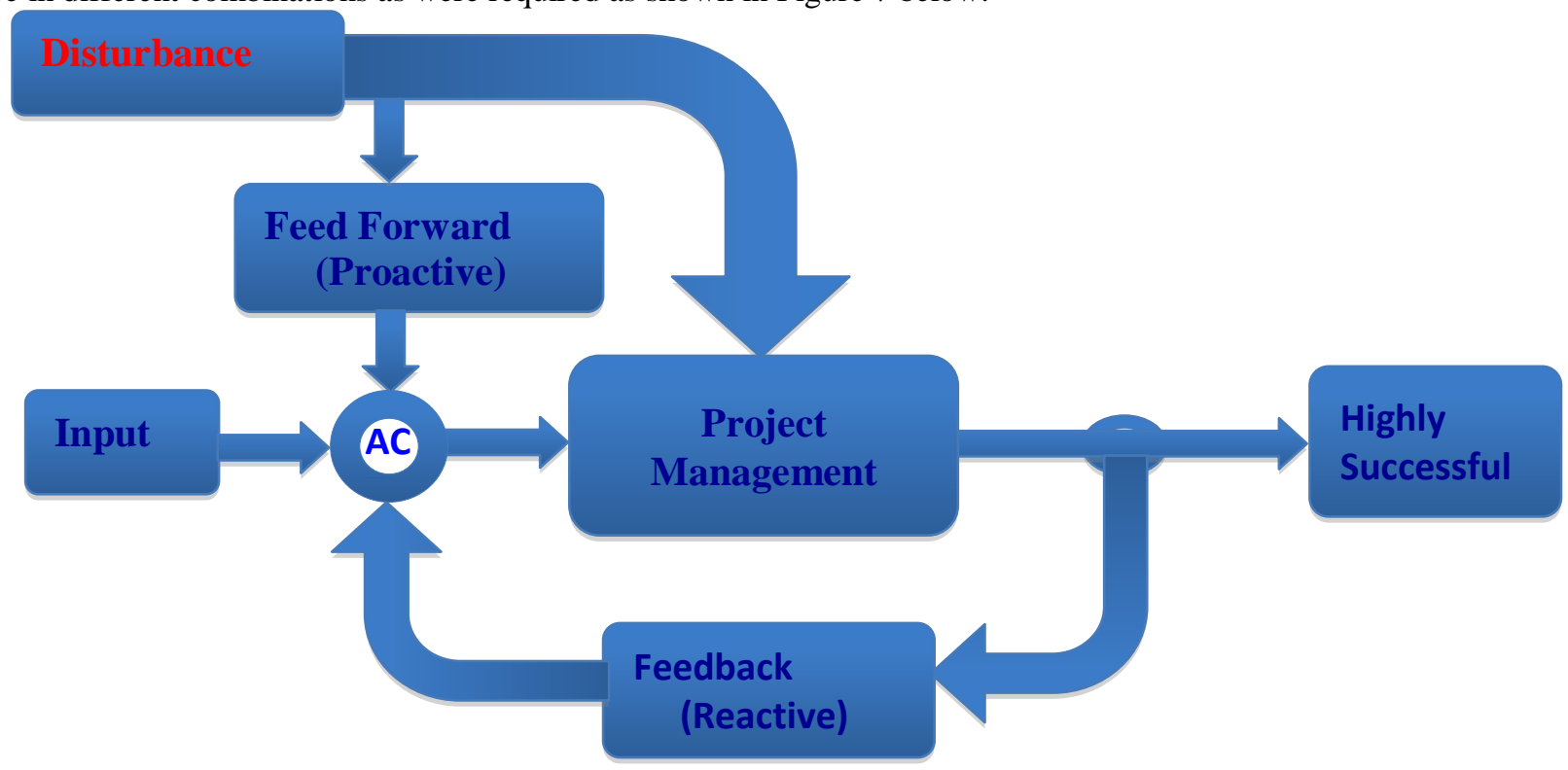

Figure 7:-Highly successful project

Disturbances include any type of changes in the environment like Political, Technological, customer requirement, Scopy, Quality standard, Competetors game plan, Employee turnover to that matter any change which effects the success of the project.

\section{Conclusion:-}

Proactive Leadership has the high potential for successful project management by changing the mindset of the people associated with the projects. Once the mindset is changed then the involvement of the users will become maximum,the way they look at the problems will be different and projects success rate will be increased. The best way to make the most of the software projects successful is the order of the day. With the advancements in technology and the most efficient and able human resources are available but still why projects are failing or challenged? It is believed that the setting right the mindset will be most economical way of solving the problems. Also the reason's for the failure must be investigates andanalyzed thoroughly may be country wise and further more areawise so that we can customizeand tailor made solutions.

"The roots of our problems are: Wealth without work, Pleasure without conscience, Knowledge without character, Commerce without morality, Science without humanity, Worship without sacrifice, Politics without principles." - 
Mohandas K. Gandhi Projects will be successful if all the leader's and team members understand and eliminate the root causes of problems as stated by Father of nation above.No single style of leadership fits to all situations and hence one must try to adapt the suitable style of Leadership based on situations keeping the proactive style common for all situations.However it can be concluded that by adopting combination of proactive leadership and reactive leadership as per suitability projects can be managed highly successful. This paper suggests for much more improvement is possible and lot of scope for further research for role of proactive leadership and Success control system for successfully managing projects.

\section{References:-}

1. Project Management Institute. Project management-a proven process for success. URL: http://www.pmi.org/projectmanagement/success.htm

2. Proactive Leadership - Dana and Bruce Brown

3. A guide to Project Management Body of Knowledge(PMBOK) $-5^{\text {th }}$ edition. http://delphinustmc.co.uk/are-youa-proactive-leader-or-a-reactive-leader-and-which-style-is-more-effective-in-the-workplace

4. The Bhagavad Gita by Mahatma Gandhi http://sites.uci.edu/chpleaders/2012/03/12/reactive-or-proactive-styleof-leadership-which-is-your-most-prominent http://www.umsl.edu/ sauterv/analysis/6840_f03_papers/frese/

5. Einstein in own words by Markus Rovito http://www.erikseberconsulting.co,/blog/chaos2015 http://ezinearticles.com/?Proactive-Leadership-Versus-Reactive-Leadership\&id=5284921

6. Proactive Behavior: Meaning, Impact, Recommendations. Source: Business Horizons, May/Jun99, Vol. 42 Issue 3, p63, 8p, 1bw Author(s): Bateman, Thomas; Crant, J. Michael

7. The Laws of Leadership By John C Maxwell

8. Project Management: Strategic Design \& Implementation, 5th Ed., (2006) David I. Cleland and Lewis R. Ireland http://whatis.techtarget.com/definition/millennials-millennial-generation

9. Leaders on Leadership by George Barna http://en.wikipedia.org/wiki/Project_manager

10. Project Manager's Portable Handbook, 2nd Ed. (2004) David I. Cleland and Lewis R. Ireland

11. 5 states of success by Brendan Foley http://www.johnmaxwell.com/blog/5-levels-of-leadership https:/www.mindtools.com/pages/article/newLDR_84.htm https:/www.legacee.com/types-of-leadershipstyles/

12. Good to Great by Jim Collins https://hbr.org/2007/07/contextbased-leadership-1

13. Successful Project Management by Trevor L Y https:/www.google.co.in/search?q=proactive+leader+pictures\&tbm $=$ isch\&tbo $=$ u\&source $=$ univ\&sa $=X \& v e d=0 a$ hUKEwiGoraX8qDVAhVFJZQKHXLcCZYQ7AkIPw\&biw=1440\&bih=680\#imgrc=vaHasRGQuWDO4M:

14. https://www.google.co.in/search? $\mathrm{q}=$ proactive+leader+pictures\&tbm $=$ isch\&tbo $=\mathrm{u} \&$ source $=$ univ \&sa $=\mathrm{X} \& v e d=0 \mathrm{a}$ hUKEwiGoraX8qDVAhVFJZQKHXLcCZYQ7AkIPw\&biw=1440\&bih=680\#imgrc=4I5mDOm7sAPeOM:http s://www.stephencovey.com/8thHabit/8thhabit.php https:/www.slideshare.net/HaseebEjaz/8-habits-of-highlyeffective-people-48699106

15. Leadership Bible by John C Maxwell Timeless Leadership 18 Leadership Sutras from The Bhagavad Gita byDebashisChatterjee. 